\title{
LANGKAH CERDAS BERMEDIA SOSIAL DI KALANGAN SANTRI MILENIAL
}

\author{
Naila Dwi Afwiyana ${ }^{1}$, Yusuf Amrozi ${ }^{2}$, Thoi'atul Falihah ${ }^{3}$ \\ ${ }^{1}$ Universitas Islam Negeri Sunan Ampel Surabaua \\ ${ }^{2}$ Universitas Islam Negeri Sunan Ampel Surabaya \\ ${ }^{3}$ Sekolah Tinggi Agama Islam Al-Anwar Sarang \\ Correspondence Author: H06217016@uinsby.ac.id
}

\begin{tabular}{|c|c|}
\hline Info Artikel : & ABSTRACT \\
\hline \multirow[t]{2}{*}{$\begin{array}{l}\text { Sejarah Artikel : } \\
\text { Menerima : } 11 \text { Juni } \\
\text { Revisi : } 15 \text { Juni } \\
\text { Diterima : } 10 \text { Juli } \\
\text { Online : } 30 \text { Juli } \\
\text { Keyword : } \\
\text { information, } \\
\text { social media, } \\
\text { santri }\end{array}$} & $\begin{array}{l}\text { In a highly sophisticated digital era where information is easily accessible and } \\
\text { abundant, social media is a means to exchange information and } \\
\text { communication, in its current development social media is widely misused for } \\
\text { certain purposes, for example disseminating information that is not in } \\
\text { accordance with reality or hoax news. This is what needs to be underlined, the } \\
\text { millennial role, especially the military students, must be able to sort out and be } \\
\text { smart in disseminating appropriate information. Recognized or not, the } \\
\text { younger generation has dominated in Indonesia. Including young students. So, } \\
\text { in this era, the students are expected to remain rigorous and intelligent in } \\
\text { disseminating quality content on social media. Without having to reduce or } \\
\text { add to the content. At this point, the role of santri in the millennial era is very } \\
\text { necessary. The students in the millennial era must actively participate in } \\
\text { disseminating and participating in social media, both in disseminating } \\
\text { information and not easily provoked or consumed by hoax information. }\end{array}$ \\
\hline & INTISARI \\
\hline $\begin{array}{l}\text { Kata Kunci : } \\
\text { informasi, } \\
\text { media sosial, } \\
\text { santri }\end{array}$ & $\begin{array}{l}\text { Di era digital yang serba canggih dimana informasi serba mudah di dapat dan } \\
\text { serba melimpah, Media sosial merupakan sarana untuk bertukar informasi dan } \\
\text { komunikasi, dalam perkembangannya saat ini media sosial banyak disalah } \\
\text { gunakan untuk kepentingan tertentu, contohnya menyebarkan informasi yang } \\
\text { tidak sesuai dengan kenyataanya atau berita hoax. Disinilah yang perlu digaris } \\
\text { bawahi, peran milenial khususnya santri milenial harus bisa memilah dan } \\
\text { cerdas dalam menyebarkan informasi yang sesuai. Diakui atau tidak, generasi } \\
\text { muda telah mendominasi di Indonesia. Termasuk juga santri muda. Maka, } \\
\text { diera milenial ini, para santri diharapkan tetap teliti dan cerdas dalam } \\
\text { menyebarkan konten berkualitas di media sosial. Tanpa harus mengurangi } \\
\text { maupun menambahi konten tersebut. Pada titik inilah, peranan santri di era } \\
\text { milenial sangat diperlukan. Para santri di era milenial harus aktif ikut } \\
\text { menebarkan dan ikut berpartisipasi dalam bermedia sosial, baik dalam } \\
\text { menyebarkan informasi maupun tak mudah terprovokasi maupun termakan } \\
\text { informasi hoax. }\end{array}$ \\
\hline
\end{tabular}




\section{PENDAHULUAN}

Perkembangan teknologi informasi di masa sekarang sangatlah berkembang. Teknologi informasi yang diikuti dengan adanya media massa yang telah memberi banyak perubahan pada kehidupan masyarakat. Di era digital yang serba canggih dimana informasi serba mudah di dapat dan serba melimpah, Media sosial merupakan sarana untuk bertukar informasi dan komunikasi, dalam perkembangannya saat ini media sosial banyak disalah gunakan untuk kepentingan tertentu, contohnya menyebarkan informasi yang tidak sesuai dengan kenyataanya atau berita hoax.

Hasil kajian Asosiasi Penyelenggara Jasa Internet Indonesia (APJII), pada tahun 2016, menyebutkan bahwa tingkat penggunaan internet Indonesia mencapai 132 juta jiwa. Kondisi yang demikian itu belum termasuk pengguna internet melalui telepon pintar (smart phone) yang mencapai 100 juta orang. Lebih jauh, sebagaimana disinggung oleh Al Mahfud dalam artikel sebelumnya, bahwa berdasarkan data Kominfo, ada 30 juta anak-anak dan remaja di Indonesia merupakan pengguna internet. Data mengungkapkan bahwa pemakai smartphone di Indonesia kisaran 1,25 kali jumlah penduduk di Indonesia. Faktanya cukup banyak pengguna sosial media ataupun situs online kisaran usia remaja.

Menurut data dari Kementrian Kominfo di akhir tahun 2016 ada sekitar 800ribu situs terindikasi menyebarkan hoax dan ujaran kebencian. Tentunya menjadi perhatian khusus agar pengguna situs online mampu mengidentifikasi dengan baik terhadap situs maupun berita yang terindikasi menyebarkan hoax.

Menurut data di atas dapat diketahui bahwa mayoritas pengguna internet atau spesifiknya media sosial adalah kaum milenial. Berdasarkan teori psikologi pemuda, ada sebuah perkembangan emosi psikologi pemuda yang ditandai dengan meninkatnya sifat sensitif, reaktif yang kuat, emosinya bersifat negatif dan temperamental (mudah tersinggung, marah, sedih, dan murung). Bersamaan dengan itu, pemuda juga selalu dihantui dengan rasa ingin tahu yang lebih dalam. Semua itu merupakan gejala yang terjadi pada masa awal usia remaja. Sementara usia akhir remaja ditandai dengan lebih matangnya pemikiran (dewasa), memiliki pendirian yang kuat, idealis, obsesif, dan lain sebagainya.

Dalam kondisi seperti diatas, sangat wajar apabila kaum milenial khususnya para santri milenial dalam bermedia sejatinya harus menjadi sosok yang mampu dijadikan sebagai figur teladan dalam bermedia. Namun sayang, kebanyakan pemuda saat ini tidak menanamkan sifat idealis dalam menggunakan media. Artinya, kalangan muda saat ini justru banyak yang terprovokasi oleh berita hoax atau palsu. Secara sengaja dan tidak sengaja, ia menjadi bagian dari penyebaran berita hoax dan fitnah sehingga memunculkan kebencian di tengah masyarakat. Kebencian tersebut tidak semakin dibumi hanguskan, melainkan semakin dipupuk sehingga rawan terhadap perpecah-pecahan.

Menurut Wasid Mansyur, salah satu dosen di Universitas Islam Negeri Sunan Ampel Surabaya (UINSA) "Generasi milenial adalah mereka yang lahir tahun 1980 hingga 2000, yang juga dikenal sebagai generasi Y. Dan tentu saja di dalamnya ada elemen santri. Dengan memaparkan hasil yang didapat salah satu lembaga riset, angka generasi milenial tersebut mencapai 81,27 juta jiwa dan disusul generasi berikutnya yakni 68,02 juta jiwa. Ini artinya bahwa masa depan bangsa Indonesia ditentukan generasi muda yang mendominasi jumlah penduduk seluruhnya, mempertahankan NKRI harus tetap terbawa di sanubari santri yang merupakan bagian tak terpisahkan dari generasi muda. Karena itu santri milenial juga harus cerdas menggunakan sejumlah sarana termasuk media sosial untuk menyebarkan konten berkualitas dan bernada damai."

Peran santri milenial sebagai salah satu mayoritas pengguna media sosial-yang menjadi media mendapatkan dan menyebarkan sebuah informasi di masyarakat. Hal ini dimaksudkan untuk 
mengimbangi sekaligus memerangi upaya sistematis penyebaran berita hoax, yang disengaja oleh kelompok tertentu.

\section{METODE PENELITIAN}

Metode penulisan bersifat studi pustaka. Informasi didapatkan dari berbagai literatur dan disusun berdasarkan hasil studi dari informasi yang diperoleh. Penulisan di upayakan saling terkait antar satu sama lain dan sesuai dengan topik yang dibahas. Metode yang digunakan dalam penelitian ini adalah metode penelitian deskriptif kualitatif. Penelitian deskriptif kualitatif adalah penelitian yang menggambarkan atau melukiskan objek penelitian berdasarkan fakta-fakta yang tampak atau sebagaimana adanya.

\section{PEMBAHASAN}

Generasi Milenial adalah sebutan untuk generasi yang lahir tahun 1980-200-an. Tentu saja didalamnya terdapat generasi Santri. Generasi itu juga disebut Generasi Praktis, karena untuk mendapatkan informasi hanya dengan mengakses internet. Generasi Milenial sebetulnya bias karena terpengaruh kategorisasi demografik masyarakat Barat.

Pada saat ini media sosial (medsos) menjadi suatu media yang memiliki peran penting dalam kehidupan kita. Perkembangannya sangat pesat. Pada saat ini perkembangannya berdampak pada kian terbukanya akses medsos yang semakin luas. Keadaan ini memicu fenomena globalisasi, sebagai hasil dari perkembangan teknologi di bidang telekomunikasi yaitu internet dan mobile phone. Dampak kian cepatnya arus informasi adalah batas-batas antarnegara dan dunia semakin kabur.

Generasi muda dengan segudang potensi yang dimilik, sudah saatnya untuk menjadi pionir atau penggerak perkembangan medsos. Generasi muda zaman now yang merupakan penghuni dari internet atau hidup di zaman internet, sudah sepantasnya bukan hanya menjadi pengguna yang pasif. Mereka bukan sekadar melihat. Mereka harus menjadi pengguna yang berpartisipasi aktif sebagai pembuat konten blog, pemberi kritik dan saran pada forum online.

\section{A. Langkah Mengetahui Berita Hoax}

Untuk mengetahui berita yang dibaca melalui sosial media termasuk berita hoax atau tidak, harus diteliti dalam membaca. Sebelum share berita cermati dahulu judulnya mengandung unsur provokatif atau tidak. Apabila menemukan judul provokatif carilah berita serupa. Lebih amannya lagi apabila membaca berita melalui situs berita resmi.

Menurut catatan Dewan Pers sekitar 43.000 situs di Indonesia mengklaim sebagai situs berita online. Namun, situs berita online resmi hanya sekitar 300 situs. Bisa disimpulkan bahwa apapun berita yang dibaca teliti dulu sumbernya, dari situs terpercaya atau tidak. Setelah meneliti alamat situsnya kemudian cari faktanya. Berita tersebut hanya sebuah opini dari penulis atau memang benar-benar fakta. Kemudian cek keaslian foto ataupun video yang terdapat dalam berita. Masukkan foto melalui google image, melalui cara ini akan ketahuan situs sumber keaslian foto tersebut. Sedangkan untuk video amati dengan cermat, video tersebut merupakan video editing atau benar-benar video asli.

\section{B. Santri Harus Mengejar Keterlambatan Dalam Bidang Teknologi}

Perkembangan Ilmu Pengetahuan dan Teknologi (IPTEK) adalah tantangan terberat santri zaman sekarang. Maklum, beberapa pesantren memang melarang penggunaan gawai dan perangkat elektronik. Ini tentu sebuah dilema. Sebab, di masa lalu, Islam pernah jaya justru karena ilmu 
pengetahuan. Daya literasi santri dan umat Islam yang semakin lama semakin rendah. Padahal, wahyu pertama yang diturunkan kepada Nabi Muhammad adalah anjuran untuk membaca.

Oleh karena itu, seorang santri harus harus dibekali pendidikan yang tidak hanya bertujuan menguatkan aqidah, ibadah dan ahklak namun juga bekal ilmu pengetahuan umum dan wawasan kebangsaan. Melalui proses tersebut, diharapkan menghasilkan santri yang tak hanya ahli dalam ilmu agama, namun juga menguasai teknologi untuk terlibat untuk menjaga persatuan. Di sisi yang lain, berkembangnya teknologi informasi yang sangat pesat merupakan kesempatan bagi para santri dalam menyiarkan wawasan Islam yang moderat. Tanpa menguasainya, niscaya para santri akan tertinggal jauh dari perkembangan tersebut.

\section{Adab Harus Tetap Nomor Satu}

Meski harus melek teknologi, santri tetap harus mengedepankan akhlak ketimbang apapun. Seberapa tinggi ia kuliah, seberapa banyak harta yang dimiliki, hingga setinggi apapun jabatannya, seorang santri harus tunduk terhadap kiainya dan mereka yang memiliki ilmu. Adab merupakan ciri khas yang harus dimiliki seorang santri ketika dia berada di pondok pesantren, santri di tuntut untuk memiliki adab dan akhlak yang baik ketika berada dimanapun.

\section{Peran Santri Milenial dalam Menghadapi Era Serba Hoax}

Kesadaran masyarakat akan informasi yang bermutu dan faktual masih rendah. Terbukti, hasil penelitian yang dilakukan oleh Kementerian Pendidikan dan Kebudayaan (Kemendikbud) dan Kementerian Komunikasi dan Informatika (Kemenkominfo) menunjukkan bahwa kaum intelektual dengan gelar doktor dan profesor sekalipun ikut menjadi korban berita-berita bohong (hoax). Fakta ini mencerminkan bahwa kesadaran literasi dan verivikasi berita di masyarakat kita masih rendah. Memang, kampanye untuk melwan berita palsu dan fitnah sudah digencarkan oleh pemerintah dan berbagai LSM di hampir seluruh kota-kota besar. Namun usaha itu tidak akan optimal manakala pemuda tidak diudukasi menjadi pemuda yang cerdas dan kritis dalam bermedia.

Melek teknologi dan beradab saja nyatanya tak cukup. Tugas berat lain seorang santri adalah menjadi ujung tombak dalam urusan literasi. Selepas lulus dari pesantren, mereka akan terjun langsung di tengah era serba hoaks seperti saat ini. Setidaknya hal itu diakui oleh pemuka agama lain, Pendeta Martin Lukito Sinaga. Ia mengatakan bahwa santri merupakan kalangan terpelajar yang harus menelaah berbagai kitab agama dan menularkan kepada masyarakat luas.

Dengan kata lain, peran pemuda maupun santri milenial sebagai mayoritas pengguna media sosial-yang menjadi media mendapatkan dan menyebarkan sebuah informasi di masyarakat. Hal ini dimaksudkan untuk mengimbangi sekaligus memerangi upaya sistematis penyebaran berita hoax, yang disengaja oleh kelompok tertentu. Setidaknya ada beberapa hal yang harus dilakukan oleh pemuda dalam kaitannya menjadi orang yang cerdas dalam bermedia.

Pertama, tanamkan literasi media. Membaca dengan teliti menjadi salah satu modal utama menjadi orang yang cerdas dalam bermedia. Sebab, dalam literasi ada nilai verivikasi konten berita. dari verifikasi tersebut akan melahirkan apakah konten berita tersebut valid atau hoax. Langkah verifikasi pertama adalah cros check berita tersebut apakah benar-benar bersumber dari media yang kredibel, kompeten, dan independen. Puncaknya, verivikasi akan menimbulkan sebuah sikap memilah mana berita palsu.

Kedua, kritis terhadap media. Haris Sumadiria (2016) mengatakan bahwa Indonesia telah menikmati reformasi serta demokratisasi pers dan penyiaran sejak 1998. Media massa Indonesia bersuka cita. Tidak ada lagi sensor dan pemberedelan (meskipun saat ini sudah ada UU ITE). Perusahaan pers tidak lagi memerlukan izin. Silahkan dirikan dan terbitkan. Maka, situs-situs online pun berkeliaran. Bersamaan dengan menjamurnya media online maupun lainnya, informasi sampah berkeliaran. Saling hujat sana dan sini. Saling menyerang kelompk satu dan lainnya menjadi fenomena yang lazim terjadi. Eranya sudah berubah menjadi perang media.

Terakhir, santri harus turut menjadi bagian dalam melawan media atau situs hoax. Dengan cara melaoprkan situs yang terbukti menyebarkan kebencian dan provokasi terhadap kelompok tertentu. 


\section{KESIMPULAN}

Kesimpulan dari uraian yang telah dijelaskan, dapat diambil beberapa kesimpulan yaitu :

1. Media sosial merupakan sarana untuk bertukar informasi dan komunikasi, dalam perkembangannya saat ini media sosial banyak disalah gunakan untuk kepentingan tertentu, contohnya menyebarkan informasi yang tidak sesuai dengan kenyataanya atau berita hoax.

2. Generasi Milenial adalah sebutan untuk generasi yang lahir tahun 1980-200-an. Tentu saja didalamnya terdapat generasi Santri. Generasi itu juga disebut Generasi Praktis, karena untuk mendapatkan informasi hanya dengan mengakses internet. Generasi Milenial sebetulnya bias karena terpengaruh kategorisasi demografik masyarakat Barat.

3. Untuk mengetahui berita yang dibaca melalui sosial media termasuk berita hoax atau tidak, harus diteliti dalam membaca. Sebelum share berita cermati dahulu judulnya mengandung unsur provokatif atau tidak. Apabila menemukan judul provokatif carilah berita serupa. Lebih amannya lagi apabila membaca berita melalui situs berita resmi.

4. Seorang santri harus harus dibekali pendidikan yang tidak hanya bertujuan menguatkan aqidah, ibadah dan ahklak namun juga bekal ilmu pengetahuan umum dan wawasan kebangsaan. Melalui proses tersebut, diharapkan menghasilkan santri yang tak hanya ahli dalam ilmu agama, namun juga menguasai teknologi untuk terlibat untuk menjaga persatuan

5. Adab merupakan ciri khas yang harus dimiliki seorang santri ketika dia berada di pondok pesantren, santri di tuntut untuk memiliki adab dan akhlak yang baik ketika berada dimanapun.

6. Ada beberapa hal yang harus dilakukan oleh pemuda dalam kaitannya menjadi orang yang cerdas dalam bermedia. Pertama, tanamkan literasi media. Kedua, kritis terhadap media. Terakhir, santri harus turut menjadi bagian dalam melawan media atau situs hoax 


\section{DAFTAR PUSTAKA}

APJII. 2016 . Profil Penggunaan Internet Indonesia. (Edisi Pertama). Jakarta : APJII

Rahman, Vanny 2018, Santri dan Sejuta Tuntutan di Era Millennia, dilihat 1 Juni 2019,

<https://jatim.idntimes.com/news/indonesia/vanny-rahman/santri-dan-sejuta-tuntutan-ditengah-era-millennial/full>.

Al Huda, Shalhan Rizki 2018, Generasi Milenial Dan Media Sosial, dilihat 1 Juni 2019,

<https://communication.binus.ac.id/2018/04/04/generasi-milenial-dan-media-sosial/>

Andriansyah, Moch 2017, Resolusi Jihad Era Milenial: Santri Wajib Cerdas Gunakan Medsos, dilihat 1 Juni 2019,

$<$ https://www.merdeka.com/peristiwa/resolusi-jihad-era-milenial-santri-wajib-cerdas-gunakanmedsos.html> 